Human and Animal Health

Vol.60: e17160325, January-December 2017 http://dx.doi.org/10.1590/1678-4324-2017160325 ISSN 1678-4324 Online Edition

\title{
Growth and Mineral Nutrition of the Chickpea (Cicer arietinum L.)-Rhizobia Symbiosis under Water Deficit
}

\author{
Ahmed Khadraji ${ }^{1}$, Mohammed Mouradi ${ }^{1}$, Cherki Ghoulam ${ }^{1 *}$. \\ ${ }^{1}$ Unit of Plant Biotechnology and Symbiosis Agrophysiology, Faculty of Sciences and Techniques, Marrakesh, \\ Morocco.
}

\begin{abstract}
The effect of the water deficit on the fresh and dry weight in the various parts of the plant and on several mineral processes in different symbiotic combinations for the chickpea (Cicer arietinum L.) varieties was studied. The experiment was undertaken in the greenhouse during five weeks. Seedlings were separately inoculated with a suspension of three rhizobia strains and were grown under water deficit (50\% of field capacity). Our results showed that the inoculation with the adequate rhizobia may improve the chickpea dry weight by improving the nodules weight, increase NR activity and more $K^{+}$accumulation under water deficit. Generally, MC0415 $\left(S_{1}\right)$ strain gives the best results, particularly in the dry weight nodules (5\% of reduction) and in parallel higher NR activity was notedinthenodule systems $\left(0.8 \pm 0.02 \mu \mathrm{mol} \mathrm{NO}{ }_{2}^{-} \mathrm{g} \mathrm{FW} \mathrm{F}^{l} \mathrm{~h}^{-1}\right)$ with the combination V46-S $\mathrm{S}_{1}$. We note a strong correlation between the dry weights of the various parts of the plantand the studied variables (NRA, Na+, andK+).
\end{abstract}

Keywords: chickpea, nitrate reductase, $\mathrm{K}^{+} / \mathrm{Na}^{+}$ratio, tolerance, water stress.

\footnotetext{
*Authors for correspondence: c.ghoulam@uca.ma
} 


\section{INTRODUCTION}

Chickpea is the third most important pulse crop and about $15 \%$ of the world's total pulse productions belong to this crop ${ }^{1}$. In Morocco, chickpea (Cicer arietinum L.) is a very old crop; moreover, it holds an important place in the Moroccan food mode for its everyday life use and particularly in the month of Ramadan. Like all of the legumes, this species has the ability to make a specific symbiotic association with soil rhizobia for atmospheric nitrogen fixing $\left(\mathrm{N}_{2}\right.$-fixing) ${ }^{2}$. Moreover, the plants development and legume-rhizobium symbiosis are susceptible to drought stress ${ }^{3}$. In the same direction, water deficit is one of the major abiotic constraints affecting its expansion and productivity ${ }^{4}$. It severally decreases the efficiency of $\mathrm{N}_{2}$-fixing ${ }^{5}$. In addition, the rhizobia which nodulate the chickpea are very specific for their host plant ${ }^{6}$.

The water deficit negatively affects growth and nodules development and functioning in many legumes species. Reported by Mouradi et al. ${ }^{7}$, that water deficit causes significant reductions in the roots and the nodules dry weights, as well as their number in alfalfa plants. Also, this constraint caused the same effects in the soybean ${ }^{8}$. The nodulation decreases also in the chickpea under water deficit; this decrease was attributed to the decline of the water content in leaves, the reduction in the nitrogenase activity and the mineral nutrition ${ }^{9}$. Furthermore, water supply and mineral nutrition are disrupted when the plant is subjected to water deficit. So the plant will seek to restore its ionic and nutritional balance, it is the strategy of the osmotic adjustment ${ }^{10,11}$. Indeed, the stress tolerance depends on the plant genotype and variety ${ }^{12}$. Nitrate is the main nitrogen source for many plants and nitrate reductase (NR) is the first enzyme in the nitrate assimilation pathway ${ }^{13}$. In general, reductions of nitrogenase activity are common events in response to water deficit ${ }^{14}$. Drought also reduces the leaves water potential ${ }^{15}$, the concentration of certain essential ions $\left(\mathrm{Ca}^{2+}, \mathrm{K}^{+}, \mathrm{Mg}^{2+} \ldots\right)$ and other specific ions such as sodium $\left(\mathrm{Na}^{+}\right)$and chloride $\left(\mathrm{Cl}^{-}\right)$in the cytoplasm or the apoplast causing an ionic toxicity which interferes with the metabolic functions of the plant ${ }^{5}$. The accumulation of sodium $\left(\mathrm{Na}^{+}\right)$ions in the plant limits the absorption of the essential cations such as potassium $\left(\mathrm{K}^{+}\right)$and calcium $\left(\mathrm{Ca}^{2+}\right)$. The interaction between these ions influences the roots growth $^{16}$. This nutritional imbalance is a possible cause of growth reduction in the presence of stress when essential ions like $\mathrm{K}^{+}, \mathrm{Ca}^{2+}$ become limited ${ }^{17}$. In the sensitive plants, the roots contain more $\mathrm{Na}^{+}$than in the leaves ${ }^{18}$, the accumulation of $\mathrm{Na}^{+}$ion is the main cause of the observed plants damage and which the leaves are more vulnerable than the other plant parts ${ }^{19}$. The metabolic toxicity of $\mathrm{Na}^{+}$is primarily due to its competitiveness with $\mathrm{K}^{+}$for the strategic sites of the cellular functions ${ }^{20,21}$.

The drought is widely recognized as the major limiting factor to the agricultural production ${ }^{22}$. Only the adapted plants can survive in these conditions. That is the first challenge of the research programs to develop tolerant or resistant varieties to water deficit. The present study aims to estimate and compare the performance of certain symbiotic associations involving six chickpea varieties and three rhizobia strains under water deficit. The study focused on growth parameters and nutrient uptake variables under drought.

\section{MATERIALS AND METHODS}

During this work, various approaches were tested in order to evaluate the effects of water deficit on the behavior of eighteen chickpea-rhizobia symbiotic associations grown under greenhouse of the Faculty of Science and Technique, Marrakesh.

Braz. Arch. Biol. Technol. v.60: e17160325, Jan/Dec 2017 


\section{Plant Material}

Six Moroccan chickpea (Cicer arietinum L.) varieties, three, Rizki (Rz), Zhour (Zh) and Douyet (Dt) were provided by the National Institute of Agronomic Research (INRA), Settat while the other three, Farihane (Fh), V34 and V46 were supplied by INRA, Meknes.

\section{Bacterial Material}

The inoculums consist of three Mesorhizobium strains: $\mathrm{S}_{1}$ (MC0415), $\mathrm{S}_{2}$ (MC1415) and $\mathrm{S}_{3}$ (MC5155) provided by the laboratory: Unit of Plant Biotechnology and Symbiosis Agro-physiology Marrakesh; were isolated according to Vincent ${ }^{23}$ from the nodules of chickpea grown in the South of Morocco (Settat region). This study was carried out under greenhouse conditions with an approximate temperature of $30 / 18^{\circ} \mathrm{C}$ (day/night), $50-80 \%$ of relative humidity and 16 hour (h) photoperiod (22 Klux). The seeds were surface disinfected by immersion in ethanol $95 \%$ for 30 sandin 5\% sodium hypochlorite for $5 \mathrm{~min}$, then rinsed several times with sterile deionized water and germinated in Petri dishes at $28^{\circ} \mathrm{C}$. After that, the seedlings were transferred to plastic pots measuring $20 \mathrm{~cm}$ tall and $16 \mathrm{~cm}$ diameter. Each pot was filed by $2000 \mathrm{~g}$ of sterile sand and peat with the proportion 5:1 respectively with three seedlings per pot. Seven days after, the young seedlings were separately inoculated with $10 \mathrm{~mL}$ of $\mathrm{S}_{1}$ (MC0415), $\mathrm{S}_{2}$ (MC1415) and $\mathrm{S}_{3}$ (MC5155) rhizobia suspensions containing approximately $10^{8} \mathrm{CFU} \cdot \mathrm{mL}^{-1}$ (CFU $=$ Colony-forming unit). Plants were alternatively watered three times a week with the distillated water and the Hoagland nitrogen free nutrient solution during the trial period. After one week, the plants of each symbiotic combination were subjected to water deficit $(50 \%$ of field capacity). The stress was applied during five weeks. The plants were then harvested and growth and nutrient uptake parameters were measured.

Biomass Measurements: Shoots, roots and nodules were separated and their fresh weights (FW) were determined. For the dry weight (DW) measurement, all plant parts were dried in oven at $80^{\circ} \mathrm{C}$ for $48 \mathrm{~h}$. FW and DW was determined on six plants for each treatment and grouped as three replicates.

Nitrate Reductase (NR) Activity: was determined in vivo according to the method of Heuer and Plaut ${ }^{24}$. Samples of leaves were infiltrated under vacuum in $10 \mathrm{~mL}$ of $50 \mathrm{mM}$ phosphate buffer, $\mathrm{pH} 7.5$, containing $0.1 \mathrm{M} \mathrm{KNO3}$ and $0.1 \%$ Tritron X-100. After 5 minutes, samples were put in an identical solution, but without Triton X-100 and incubated during 1 hour in $28^{\circ} \mathrm{C}$. Then, $1 \mathrm{~mL}$ of extract is taken and completed with $0.25 \mathrm{~mL}$ of $1.5 \mathrm{M} \mathrm{HCl}$, containing $1 \%$ sulfanilamide and $0.25 \mathrm{~mL}$ of $\mathrm{N}$ - (1 naphtylethylenediamine) dihydrochloride $(0.02 \% \mathrm{w} / \mathrm{v}$ in aqueous solution). Absorbance at $540 \mathrm{~nm}$ was determined and NR activity was calculated by a standard curve established with $\mathrm{NaNO}_{2}$ and expressed in $\mu \mathrm{mol} \mathrm{NO}_{2}^{-} \mathrm{g} \mathrm{FW}^{-1} \mathrm{~h}^{-1}$. Three replicates per symbiosis per treatment were analyzed.

Mineral Analysis of Plants: samples were dried at $80^{\circ} \mathrm{C}$ for $48 \mathrm{~h}$ and then incinerated at $600^{\circ} \mathrm{C}$ for $4 \mathrm{~h}$. The ashes were added after that with $3 \mathrm{~mL}$ chloridric acid $6 \mathrm{~N}$, evaporated and then adjusted to $100 \mathrm{~mL}$ by hot distilled water. The concentrations of $\mathrm{Na}^{+}$and $\mathrm{K}^{+}$were determined in leaves and roots using a Jenway Flame Photometer.

Statistical Analysis was performed using SPSS (10.0) software. Two-way analysis of variance (ANOVA II) was made by using three replicates per combination per treatment for all of the studied parameters. The means values and the standard errors 
were calculated. The Tukey's test was used for the means comparison of the considered parameters.

\section{RESULTS AND DISCUSSION}

The studied varieties present significant differences between the shoots, the root systems and nodules under the water deficit for all variables studied. This is in agreement with the results found by Brugnoli and Björkman ${ }^{25}$, Bernstein et al. ${ }^{26}$.

\section{The effect of the water deficit on the biomass}

The analysis of the results $(p<0.001$, Table 1$)$ of the fresh and dry weights showed that the water deficit caused a significant reduction of the shoots, roots and nodules in comparison with their respective controls of the various studied chickpea-rhizobia combinations. These results are in agreement with the work of Ashraf and Iram ${ }^{27}$. The analysis of the fresh weight $(\mathrm{FW})$ of the chickpea varieties showed that when the plants were inoculated by the strains $S_{2}$ and $S_{3}$, they the strongest reductions among all of the studied combinations, particularly for the combinations Dt- $\mathrm{S}_{3}$ in nodules $(80 \%$ of $\mathrm{FW}), \mathrm{Zh}_{-} \mathrm{S}_{2}$ in shoots $(57 \%$ of $\mathrm{FW})$ and $\mathrm{Fh}-\mathrm{S}_{3}$ in roots $(53 \%$ of FW). The effect of the $S_{1}$ was significant $(p<0.001$, Table 1) in all of the studied varieties under water stress, especially with combination $\mathrm{V}_{46}-\mathrm{S}_{1}(6 \%, 15 \%$ and $18 \%$ reduction in nodules, shoots and roots respectively). 
Table 1:Effect of the water stress (WS) on the fresh and dry weight in the studied chickpea varieties inoculated by rhizobia strains $\left(S_{1}, S_{2}, S_{3}\right)$.

\begin{tabular}{|c|c|c|c|c|c|c|c|c|c|c|c|c|c|}
\hline \multirow{3}{*}{ Varieties } & \multirow{3}{*}{ Strains } & \multicolumn{6}{|c|}{ Fresh weight (g/6 plants) } & \multicolumn{6}{|c|}{ Dry weight (g/6 plants) } \\
\hline & & \multicolumn{2}{|c|}{ Shoots } & \multicolumn{2}{|c|}{ Roots } & \multicolumn{2}{|l|}{ Nodules } & \multicolumn{2}{|c|}{ Shoots } & \multicolumn{2}{|c|}{ Roots } & \multicolumn{2}{|l|}{ Nodules } \\
\hline & & Control & WS & Control & WS & Control & WS & Control & WS & Control & WS & Control & WS \\
\hline \multirow{3}{*}{$\mathrm{Rz}$} & S1 & $63,8^{\mathrm{ab}}$ & $35,77^{\mathrm{c}}$ & $6,16^{\mathrm{ab}}$ & $4^{b}$ & $2^{\mathrm{d}}$ & $1^{\mathrm{f}}$ & $16^{\mathrm{ab}}$ & $9^{c}$ & $1,54^{\mathrm{ab}}$ & $1^{\mathrm{b}}$ & $0,5^{\mathrm{d}}$ & $0,25^{\mathrm{f}}$ \\
\hline & S2 & $32,01^{\mathrm{fg}}$ & $16,04^{\mathrm{gh}}$ & $2,8^{\mathrm{f}}$ & $1,4^{\mathrm{e}}$ & $1^{\mathrm{fg}}$ & $0,6^{\mathrm{h}}$ & $8 f^{g}$ & $4^{\text {gh }}$ & $0,7^{\mathrm{f}}$ & $0,35^{\mathrm{e}}$ & $0,25^{\mathrm{fg}}$ & $0,15^{\mathrm{h}}$ \\
\hline & S3 & $28,01^{\mathrm{g}}$ & $12,25^{\text {hi }}$ & $2,4^{\mathrm{g}}$ & $1,31^{\mathrm{ef}}$ & $0,88^{\mathrm{g}}$ & $0,4^{\mathrm{i}}$ & $7^{\mathrm{g}}$ & $3,06^{\mathrm{hi}}$ & $0,6^{\mathrm{g}}$ & $0,33^{\text {ef }}$ & $0,22^{\mathrm{g}}$ & $0,1^{\mathrm{i}}$ \\
\hline \multirow{3}{*}{$\mathrm{Zh}$} & S1 & $56,12^{\mathrm{c}}$ & $28,01^{\mathrm{d}}$ & $5,19^{\mathrm{c}}$ & $2,82^{\mathrm{c}}$ & $1,96^{\mathrm{d}}$ & $0,81^{\mathrm{g}}$ & $14^{\mathrm{c}}$ & $7^{\mathrm{d}}$ & $1,3^{\mathrm{c}}$ & $0,7^{\mathrm{c}}$ & $0,49^{\mathrm{d}}$ & $0,2^{\mathrm{g}}$ \\
\hline & S2 & $28,01^{\mathrm{g}}$ & $12,05^{\mathrm{i}}$ & $2,4^{\mathrm{g}}$ & $1,21^{\text {egf }}$ & $0,82^{\text {gh }}$ & $0,64^{\mathrm{h}}$ & $7^{\mathrm{g}}$ & $3^{\mathrm{i}}$ & $0,6^{\mathrm{g}}$ & $0,3^{\text {ef }}$ & $0,2^{\mathrm{gh}}$ & $0,16^{\mathrm{h}}$ \\
\hline & S3 & $16^{\mathrm{hi}}$ & $7,97^{\mathrm{j}}$ & $1,8^{\mathrm{h}}$ & $1^{\text {gh }}$ & $0,56^{\mathrm{i}}$ & $0,35^{\mathrm{ij}}$ & $4^{\mathrm{hi}}$ & $2^{j}$ & $0,45^{\mathrm{h}}$ & $0,25^{\mathrm{fg}}$ & $0,14^{\mathrm{i}}$ & $0,086^{\mathrm{ij}}$ \\
\hline \multirow{3}{*}{ Dt } & S1 & $44^{\mathrm{d}}$ & $15,9^{\text {gh }}$ & $3,59^{\mathrm{e}}$ & $1,12^{\mathrm{fg}}$ & $1,27^{\mathrm{e}}$ & $0,36^{\mathrm{ij}}$ & $11^{\mathrm{d}}$ & $4^{\text {gh }}$ & $0,9^{\mathrm{e}}$ & $0,28^{\mathrm{efg}}$ & $0,32^{\mathrm{e}}$ & $0,09^{\mathrm{ij}}$ \\
\hline & $\mathrm{S} 2$ & $19,97^{\mathrm{h}}$ & $12,01^{\mathrm{i}}$ & $1,08^{\mathrm{i}}$ & $0,56^{\mathrm{ij}}$ & $0,36^{\mathrm{ij}}$ & $0,12^{\mathrm{kl}}$ & $5^{\mathrm{h}}$ & $3^{\mathrm{i}}$ & $0,27^{\mathrm{i}}$ & $0,14^{\mathrm{hi}}$ & $0,09^{\mathrm{ij}}$ & $0,03^{\mathrm{kl}}$ \\
\hline & S3 & $12,013^{\mathrm{ij}}$ & $7,99^{j}$ & $0,64^{\mathrm{j}}$ & $0,36^{\mathrm{j}}$ & $0,2^{\mathrm{j}}$ & $0,04^{1}$ & $3^{\mathrm{ij}}$ & $2^{j}$ & $0,16^{\mathrm{j}}$ & $0,09^{i}$ & $0,05^{\mathrm{j}}$ & $0,01^{1}$ \\
\hline \multirow{3}{*}{ Fh } & S1 & $12^{\mathrm{ij}}$ & $5,99^{j}$ & $1,2^{\mathrm{i}}$ & $0,8^{\text {hi }}$ & $0,6^{\mathrm{hi}}$ & $0,41^{\mathrm{i}}$ & $3^{\mathrm{ij}}$ & $1,5^{\mathrm{j}}$ & $0,3^{\mathrm{i}}$ & $0,2^{\mathrm{gh}}$ & $0,15^{\mathrm{hi}}$ & $0,1^{\mathrm{i}}$ \\
\hline & $\mathrm{S} 2$ & $10,37^{j}$ & $5,19^{j}$ & $1,08^{\mathrm{i}}$ & $0,52^{\mathrm{j}}$ & $0,48^{\mathrm{i}}$ & $0,24^{\mathrm{jk}}$ & $2,6^{j}$ & $1,3^{\mathrm{j}}$ & $0,27^{\mathrm{i}}$ & $0,13^{\mathrm{hi}}$ & $0,12^{\mathrm{i}}$ & $0,06^{\mathrm{jk}}$ \\
\hline & S3 & $9,99^{j}$ & $4,91^{\mathrm{j}}$ & $1,02^{\mathrm{ij}}$ & $0,48^{\mathrm{j}}$ & $0,44^{\mathrm{ij}}$ & $0,2^{\mathrm{k}}$ & $2,5^{j}$ & $1,2^{\mathrm{j}}$ & $0,26^{\mathrm{ij}}$ & $0,12^{\text {hi }}$ & $0,11^{\mathrm{ij}}$ & $0,05^{\mathrm{k}}$ \\
\hline \multirow{3}{*}{ V34 } & S1 & $59,87^{\mathrm{bc}}$ & $45,2^{\mathrm{b}}$ & $5,92^{\mathrm{b}}$ & $4,96^{\mathrm{a}}$ & $2,81^{\mathrm{b}}$ & $2,53^{\mathrm{b}}$ & $15^{\mathrm{bc}}$ & $11,3^{\mathrm{b}}$ & $1,5^{\mathrm{b}}$ & $1,24^{\mathrm{a}}$ & $0,7^{\mathrm{b}}$ & $0,6^{\mathrm{b}}$ \\
\hline & S2 & $36^{\mathrm{ef}}$ & $20,03^{\text {ef }}$ & $3,47^{\mathrm{e}}$ & $2,41^{\mathrm{d}}$ & $1,81^{\mathrm{d}}$ & $1,28^{\mathrm{e}}$ & $9^{\text {eff }}$ & $5^{\mathrm{ef}}$ & $0,87^{\mathrm{e}}$ & $0,6^{\mathrm{d}}$ & $0,45^{\mathrm{d}}$ & $0,32^{\mathrm{e}}$ \\
\hline & S3 & $31,87^{\mathrm{fg}}$ & $16,4 \mathrm{f}^{\mathrm{g}}$ & $2,81^{\mathrm{f}}$ & $1,32^{\mathrm{ef}}$ & $1,21^{\mathrm{ef}}$ & $0,84^{\mathrm{g}}$ & $8^{\mathrm{fg}}$ & $4,1^{\mathrm{fg}}$ & $0,7^{\mathrm{f}}$ & $0,33^{\text {ef }}$ & $0,3^{\text {ef }}$ & $0,21^{\mathrm{g}}$ \\
\hline \multirow{3}{*}{ V46 } & S1 & $68,53^{\mathrm{a}}$ & $58^{\mathrm{a}}$ & $6,36^{\mathrm{a}}$ & $5,21^{\mathrm{a}}$ & $3,21^{\mathrm{a}}$ & $3,03^{\mathrm{a}}$ & $17,13^{\mathrm{a}}$ & $14,5^{\mathrm{a}}$ & $1,6^{\mathrm{a}}$ & $1,3^{\mathrm{a}}$ & $0,8^{\mathrm{a}}$ & $0,76^{\mathrm{a}}$ \\
\hline & $\mathrm{S} 2$ & $44,13^{\mathrm{d}}$ & $27,87^{\mathrm{d}}$ & $4,45^{\mathrm{d}}$ & $2,81^{\mathrm{c}}$ & $2,41^{\mathrm{c}}$ & $2,12^{\mathrm{c}}$ & $11^{\mathrm{d}}$ & $7^{\mathrm{d}}$ & $1,1^{\mathrm{d}}$ & $0,7^{\mathrm{c}}$ & $0,6^{\mathrm{c}}$ & $0,53^{\mathrm{c}}$ \\
\hline & $\mathrm{S} 3$ & $40,13^{\text {de }}$ & $22,77^{\mathrm{e}}$ & $4,13^{\mathrm{d}}$ & $2,39^{\mathrm{d}}$ & $2,04^{\mathrm{d}}$ & $1,68^{\mathrm{d}}$ & $10^{\mathrm{de}}$ & $5,7^{\mathrm{e}}$ & $1^{\mathrm{d}}$ & $0,6^{\mathrm{d}}$ & $0,51^{\mathrm{d}}$ & $0,42^{\mathrm{d}}$ \\
\hline \multicolumn{2}{|r|}{$\mathrm{dF}$} & $\mathrm{F}$ & $\mathrm{F}$ & $\mathrm{F}$ & $\mathrm{F}$ & $\mathrm{F}$ & $\mathrm{F}$ & $\mathrm{F}$ & $\mathrm{F}$ & $\mathrm{F}$ & $\mathrm{F}$ & $\mathrm{F}$ & $\mathrm{F}$ \\
\hline Varieties & 5 & $569^{* * *}$ & $697,68^{* * *}$ & $1154,6^{* * *}$ & $1587,65^{* * *}$ & $856,7^{* * * *}$ & $3260^{* * * *}$ & $566,7^{* * *}$ & $688,35^{* * *}$ & $1151^{* * *}$ & $721,1^{* * *}$ & $857,16^{* * *}$ & $3258,7^{* * *}$ \\
\hline Strains & 2 & $1195,5^{* * *}$ & $1226,84^{* * * *}$ & $2106,4^{* * * *}$ & $2690,95^{* * *}$ & $879,37^{* * *}$ & $1507,38^{* * * *}$ & $1191,3^{* * *}$ & $1215^{* * * *}$ & $2100,4^{* * *}$ & $1224,4^{* * *}$ & $881,8^{* * * *}$ & $1508,85^{* * *}$ \\
\hline $\begin{array}{l}\text { Varieties } \\
\text { * Strains }\end{array}$ & 10 & $47,35^{* * *}$ & $95,93^{* * *}$ & $88,88^{* * *}$ & $185,8^{* * * *}$ & $32,12^{* * *}$ & $160,91^{* * *}$ & $47,22^{* * *}$ & $94,84^{* * *}$ & $88,7^{* * *}$ & $84,7^{* * * *}$ & $32,05^{* * *}$ & $160,9^{* * * *}$ \\
\hline
\end{tabular}


For the dry weights (DW), water deficit has significantly $(p<0.001$, Table 1$)$ reduced this parameter in all of the studied varieties. The results showed that when the plants inoculated with the strains $S_{2}$ and $S_{3}$ they presented the strongest reductions in comparison with the other combinations, in particular the combinations Dt- $\mathrm{S}_{3}$ in nodules ( $80 \%$ of DW), Rz-S $\mathrm{S}_{3}$ in shoots (58\% of DW) and $\mathrm{Fh}-\mathrm{S}_{2}$ in roots $(52 \%$ of DW). The symbiotic combination $\mathrm{V} 46-\mathrm{S}_{1}$ strain presented interest ingresults and particularly in the nodules biomass (6\% of DW reduction). Our results showed that the inoculation with the adequate rhizobia may improve the chickpea fresh and dry weight by improving the nodules weight under water deficit.This confirms the work published for Medicago sativa ${ }^{28,7}$, Cicer arietinum ${ }^{9}$ and the same findings were reported for Phaseolus vulgaris ${ }^{5}$. Under drought conditions, the improvement of vigour and the production of the dry matter could be under consideration like principal element for the maintenance and the improvement of the chickpea yield ${ }^{29}$.

\section{The effect of the water deficit on the nitrate reductase activity}

The results presented in the Figure1, 2 and 3 showed that the water deficit has significantly affected ( $p<0.001$, Table 2$)$ the nitrate reductase activity in the various parts of the plant compared to the controls. The activity of this enzyme is variable according to the studieds trains. Indeed, the plants inoculated by $S_{1}$ have significantly $(p<0.001)$ more raised their NR activities (15to50\%) in comparison with those inoculated by the other strains. The NR activity was significantly inhibited by stress, especially in combinations $S_{3}$ with Rizki, Zhour and Douyet varieties because observed values in the stressed plants were lower than the controls. On the other hand, we noted a significant increase of the NR activity particularly in shoots and in the nodules of the varieties V46 and V34. This variation was maximal for the $\mathrm{S}_{1}(65$ to $74 \%$ ) followed by the $S_{2}(42$ to $65 \%)$ respectively. The highest values were observed for V46 in the nodules $\left(0.8 \pm 0.02 \mu \mathrm{mol} \mathrm{NO}_{2}^{-} \mathrm{g} \mathrm{FW}^{-1} \mathrm{~h}^{-1}\right.$, Fig. 1$)$, followed by the roots $\left(0.5 \pm 0.017 \mu \mathrm{mol} \mathrm{NO}_{2}^{-} \mathrm{g} \mathrm{FW}^{-1} \mathrm{~h}^{-1}\right.$, Fig. 2) while the lowest were noted in the shoots $\left(0.28 \pm 0.015 \mu \mathrm{mol} \mathrm{NO}{ }_{2}^{-} \mathrm{g} \mathrm{FW}^{-1} \mathrm{~h}^{-1}\right.$, Fig. 3). Indeed, the activity of this enzyme is not sensitive to the osmotic effect ${ }^{30}$ and consequently our results could be explained by a low availability of $\mathrm{NO}_{3}$, the substrate of this enzyme ${ }^{31}$. In legume plants, accumulation nitrogen compounds and reductions of nitrogenase activity are common events in response to water deficit ${ }^{14}$.

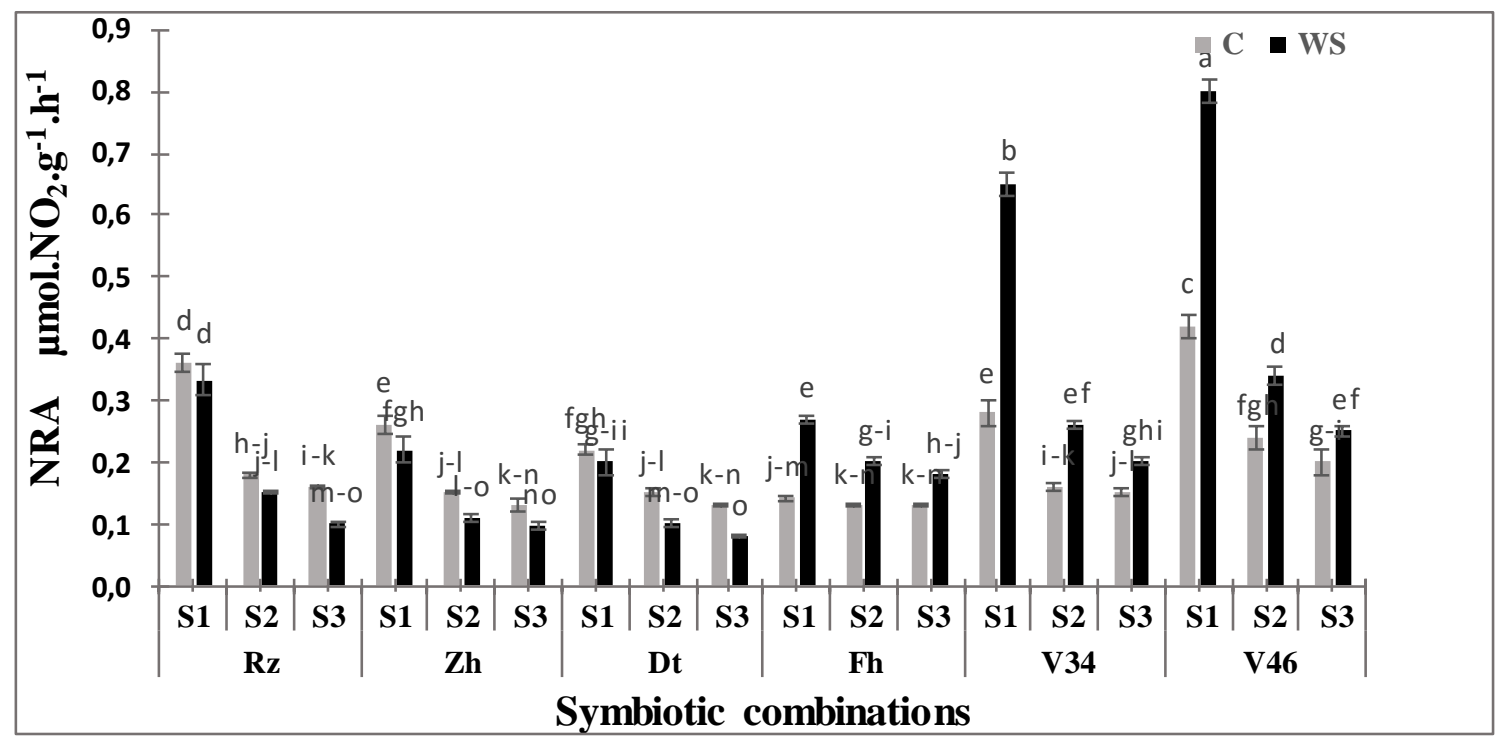

Figure 1. Effect of water deficit on NR activity in nodules of six Moroccan chickpea genotypes (Rz, Zh, Dt, Fh, V34 and V46) inoculated with rhizobial strains. Values are means of three replicates and bars represent standard errors. 


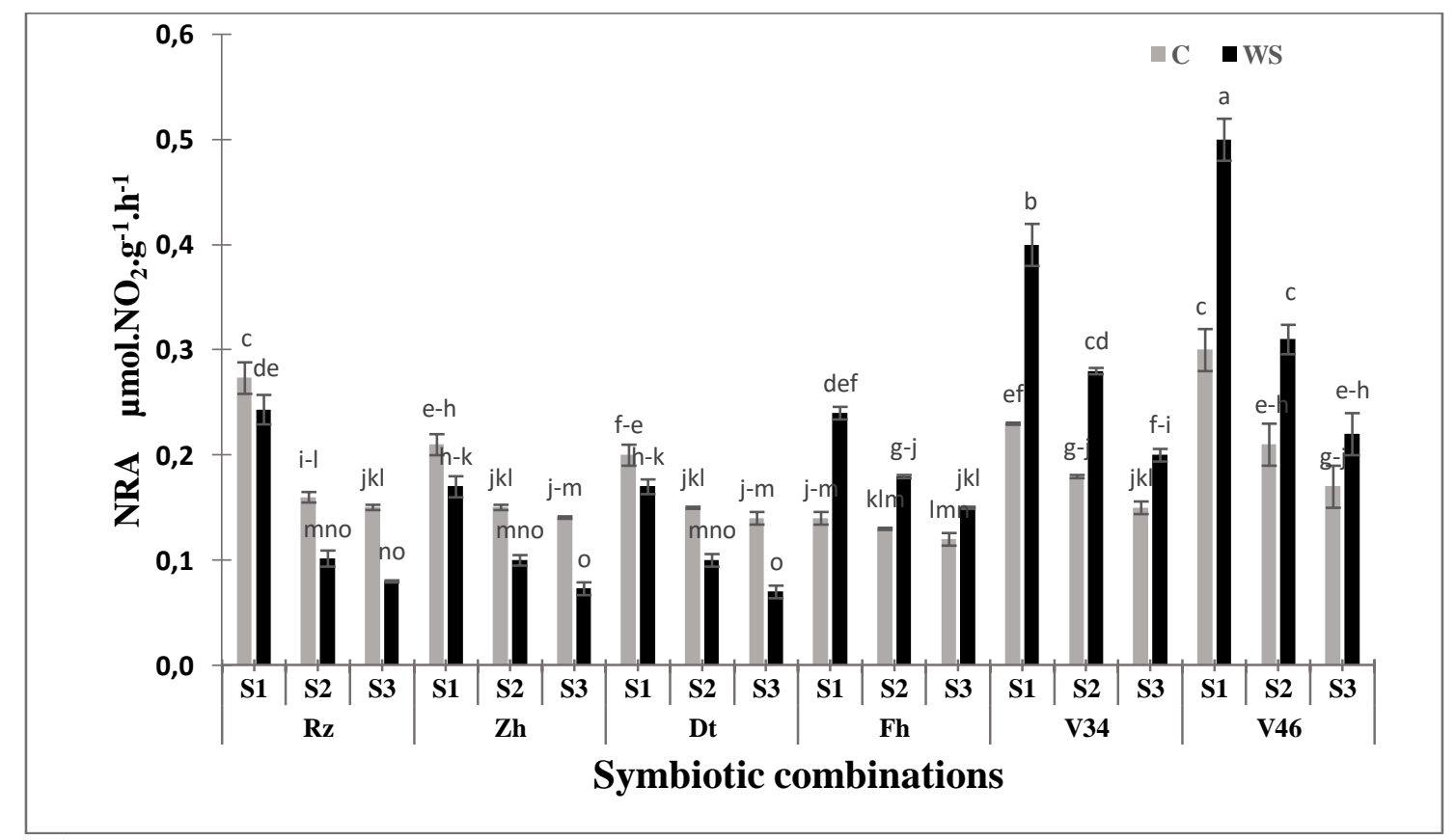

Figure 2. Effect of water deficit on NR activity in roots of six Moroccan chickpea genotypes (Rz, Zh, Dt, Fh, V34 and V46) inoculated with rhizobial strains. Values are means of three replicates and bars represent standard errors.

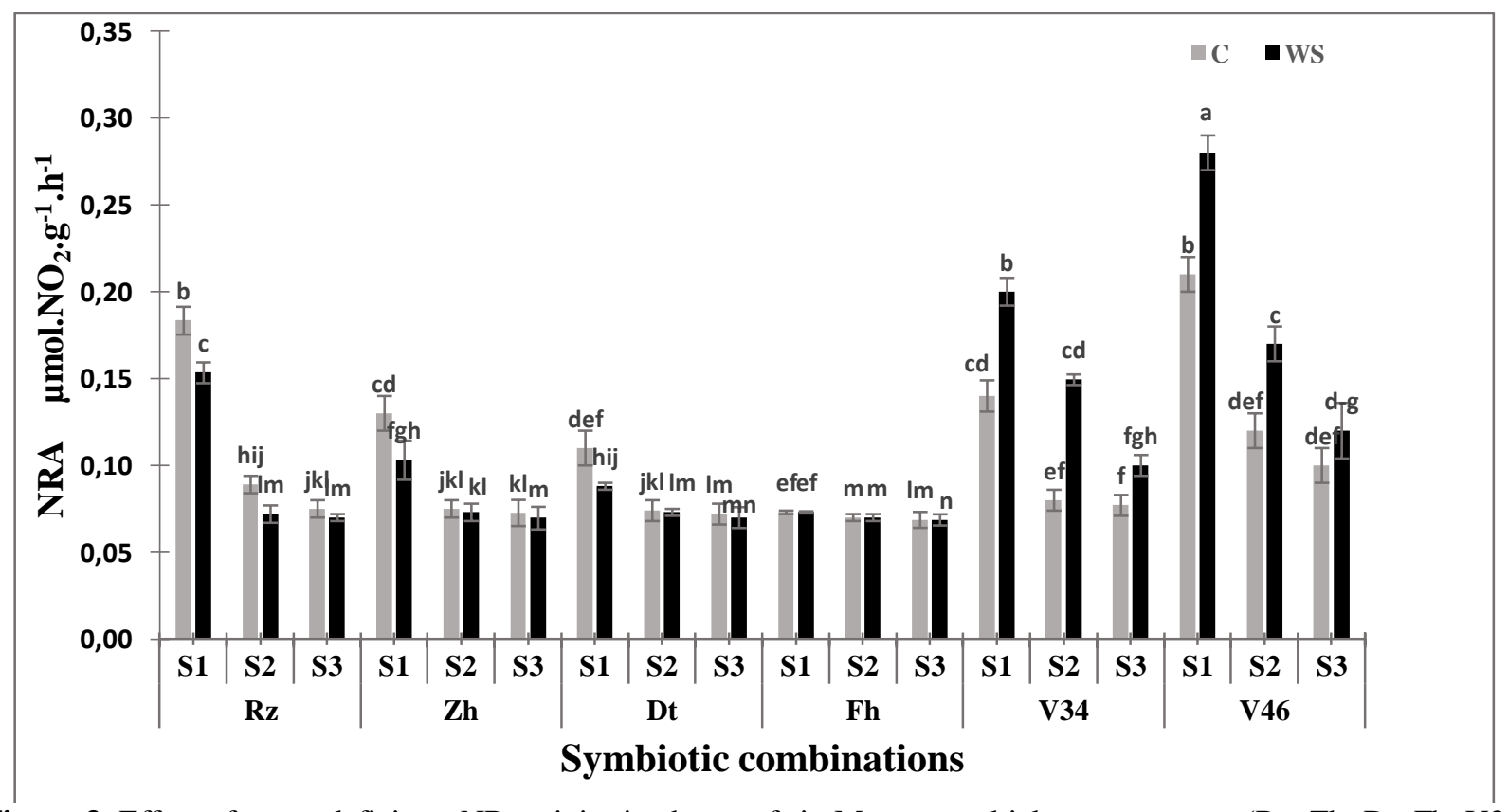

Figure 3. Effect of water deficit on NR activity in shoots of six Moroccan chickpea genotypes (Rz, Zh, Dt, Fh, V34 and V46) inoculated with rhizobial strains. Values are means of three replicates and bars represent standard errors.

\section{$\mathrm{Na}+$ content}

Figure 4, showed that the rate of $\mathrm{Na}^{+}$contents in the shoots in response to the water deficit reveals highly significant $(p<0.001$, Table 2$)$ as well as in the roots with significant variation between the studied varieties.Douyet, Zhour and Rizki accumulated high level of $\mathrm{Na}^{+}$contents in their roots in comparison with their shoots under water stress, especially when inoculated with $S_{3}$. Indeed, the maximum value was presented by Douyet under stress $\left(52 \pm 1 \mathrm{mg} . \mathrm{g}^{-1} \mathrm{DW}\right.$ and $23 \pm 0.7 \mathrm{mg} \cdot \mathrm{g}^{-1} \mathrm{DW}$ respectively).These varieties were unable to easily transport $\mathrm{Na}+$ to their shoots and thus are clearly more sensitive than the others. This inaptitude to export this ion is 
probably less protective character than the deficiency of the cellular compartmentalization system ${ }^{17}$. Indeed, these varieties are unable to remove the $\mathrm{Na}^{+}$ from the cytoplasm, which by consequence will easily transported to the phloem and they are constantly returned to the root systems ${ }^{19}$. On the contrary, the results showed that under water deficit, the combination V46-S ${ }_{1}$ accumulated a maximum $\mathrm{Na}+$ content of $44 \pm 1$ and $14.67 \pm 0.58 \mathrm{mg} \cdot \mathrm{g}^{-1} \mathrm{DW}$ respectively intheir shoots in comparison to the roots, this could be an element of drought tolerance in accordance with $^{32}$ but this behavior obviously supposes a certain control of the accumulated quantity of these ions in shoots, which does not have to disrupt the cellular osmotic balance ${ }^{33}$. Whereas, in Farihane- $\mathrm{S}_{1}$ combination, the $\mathrm{Na}^{+}$products were the same values in the roots and in the shoots $\left(24.87 \pm 0.8\right.$ and $24.8 \pm 0.76 \mathrm{mg} . \mathrm{g}^{-1}$ DW respectively).

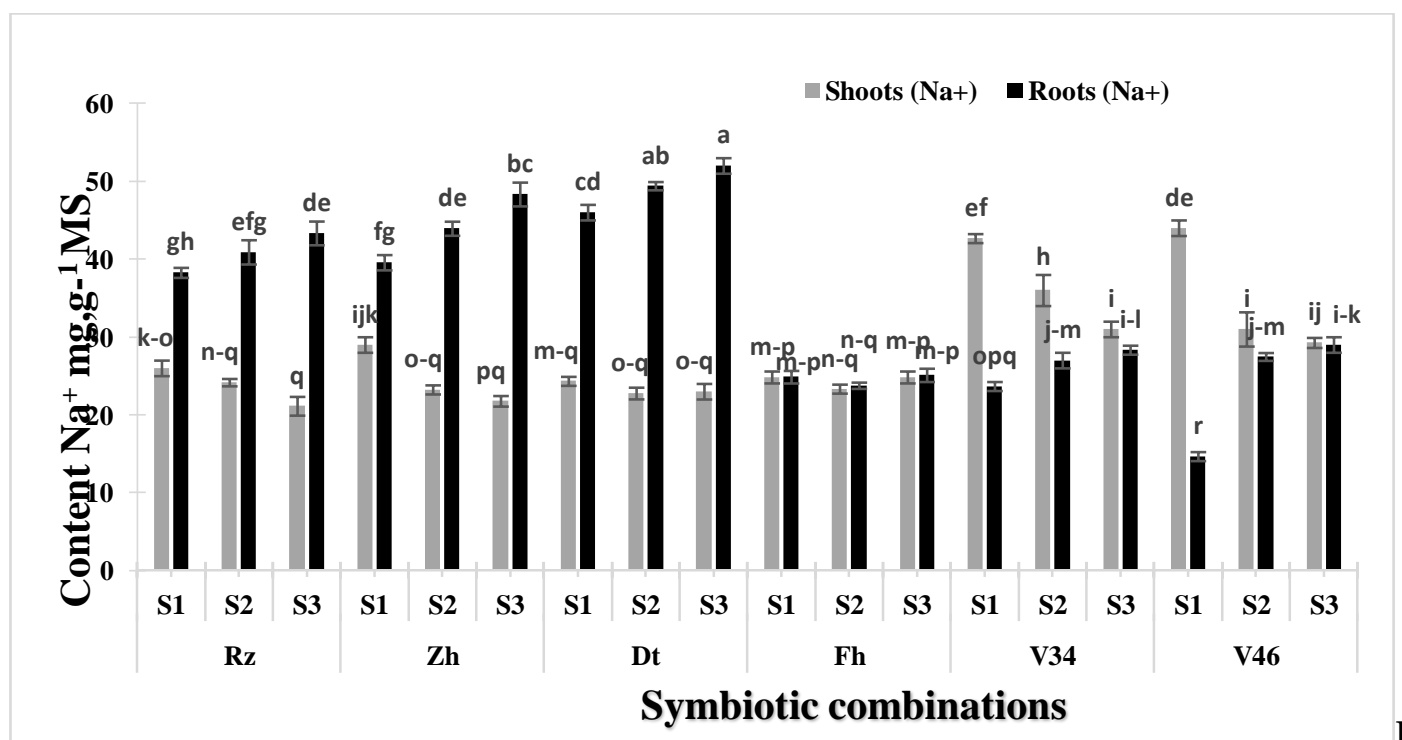

roccan chickpea genotypes (Rz, Zh, Dt, Fh, V34 and with rhizobial strains. Values are means of three replicates and bars represent standard errors.

Table 2 Mean squares values from analysis of variance 2-way (ANOVA II) of water deficit and chickpea varieties effects and their interactions with considered parameters.

\begin{tabular}{ccccccc}
\hline & $\mathrm{dF}$ & $\mathrm{FW}$ & $\mathrm{DW}$ & $\mathrm{NRA}$ & $\mathrm{Na}^{+}$ & $\mathrm{K}^{+}$ \\
\hline Varieties & 5 & $2150.3^{* * *}$ & $1853^{* * *}$ & $87^{* * *}$ & $199.3^{* * *}$ & $5798.4^{* * *}$ \\
strain & 2 & $4097.9^{* * *}$ & $3523.4^{* * *}$ & $254.8^{* * *}$ & $22.5^{* * *}$ & $6350.1^{* * * *}$ \\
Drought & 1 & $37667.9^{* * *}$ & $36560.6^{* * *}$ & $439.8^{* *}$ & $2245.2^{* * *}$ & $27875.2^{* * *}$ \\
Varieties $*$ strains & 10 & $169.5^{* * *}$ & $145.5^{* * *}$ & $12.7^{* * *}$ & $5.6^{* * *}$ & $131.9^{* * *}$ \\
Varieties*Drought & 5 & $1236.4^{* * *}$ & $1204.4^{* * *}$ & $35.2^{* * *}$ & $587.1^{* * *}$ & $312.9^{* * *}$ \\
Drought $*$ strains & 2 & $2613.8^{* * *}$ & $2564^{* * *}$ & $52.7^{* * *}$ & $207.2^{* * *}$ & $950.2^{* * *}$ \\
Varieties Strains*Drought & 10 & $105.2^{* * *}$ & $104.2^{* * *}$ & $7.99^{* * *}$ & $25.8^{* * *}$ & $65.8^{* * *}$ \\
\hline
\end{tabular}

*: Significance at 0.05 probability level; **: Significance at 0.01 probability level; ***: Significance at 0.001 probability level; NS: Not significant at 0.05 . 


\section{$\mathrm{K}+$ content}

The results (Fig.5) showed that the behavior of the studied varieties vary significantly $(p<0.001$, Table 2$)$ under water deficit. We also noted that in all of the varieties the $\mathrm{K}^{+}$contents raised in the shoots in comparison, with the roots. Indeed, the combinations $\mathrm{V} 46-\mathrm{S}_{1}$ and $\mathrm{V} 34-\mathrm{S}_{1}$ presented the highest $\mathrm{K}^{+}$contents in shoots $\left(199.7 \pm 2.5\right.$ and $181.57 \pm 3.7 \mathrm{mg} . \mathrm{g}^{-1}$ DW respectively) under stress conditions in comparison with their roots $\left(55 \pm 1.9\right.$ and $61.67 \pm 2.7 \mathrm{mg} . \mathrm{g}^{-1} \mathrm{DW}$ respectively). On the contrary, Rizki and Zhour presented higher $\mathrm{K}^{+}$contents in shoots $(99.5 \pm 0.5$ and $\left.95.7 \pm 0.7 \mathrm{mg} . \mathrm{g}^{-1} \mathrm{DW}\right)$ than in the roots under water stress $(74.27 \pm 2.6$ and $82.13 \pm 1.25$ mg. $\mathrm{g}^{-1}$ DW respectively) when inoculated with $S_{1}$. In front of water deficit, to the varieties V46 and V34 accumulated more $\mathrm{K}^{+}$products in their shoots which increases the water absorption. Furthermore, the potassium was a major plant macronutrient and plays important roles to osmoregulation, stomatal behavior, membrane polarization and neutralization of no diffusible negatively charged ions ${ }^{34}$. This cation is considered as the first element against the adverse effects of stress ${ }^{35}$ and the key element for the tolerance to the abiotic constraints due to its capacity in the osmotic adjustment ${ }^{36}$. On the other hand, important potassium deficiency under stress leads to plant dehydration ${ }^{37}$; causes the stomata closure and consequently, led to a low transpiration level. For a wide range of varieties, it is often found that plants that are more able to tolerate moderately drought environments have a greater ability to exclude $\mathrm{Na}^{+}$from the shoots, or maintain high levels of $\mathrm{K}^{+38}$. The results showed that the selectivity of the $\mathrm{K}^{+}$in the leaves shows its aptitude to limit the transport of $\mathrm{Na}+$ and to reduce its toxicity.Such behavior was observed on some varieties of maize $^{39}$ and rice ${ }^{40}$. In the same context, many authors announced that the tolerant plants maintain an important $\mathrm{K}+\mathrm{Na}+$ ratio in their shoots following a selection of the $\mathrm{K}+$ and $\mathrm{Na}+$ absorption in the roots ${ }^{41,42,43}$. Besides, our results showed that the reduction of the fresh and dry weight in the chickpea generally coincides with the increase of the $\mathrm{Na}^{+}$contents and the reduction of the $\mathrm{K}^{+}$contents. Indeed, the dry weight of the shoots is strongly correlated with NR activity $\left(r=0.521^{* * *}\right)$, with $\mathrm{Na}+$ contents $\left(r=0.836^{* *}\right)$ and with $\mathrm{K}+$ accumulation $\left(r=0.898^{* *}\right)$ under water deficit. The nodules dry weight is also strongly correlated with the nitrate reductase activity $\left(r=0.895^{* *}\right)$ under drought condition. Similar results were reported for other species such as Phaseolus ${ }^{44}$. The tolerance of legumes plants under the drought conditions is related to adaptive processes which imply the movement of ion, the biosynthesis and the organic accumulation of osmolytes taking in account the osmotic adjustment and the protein reorganizations important for the preservation of the cellular integrity ${ }^{45}$. 


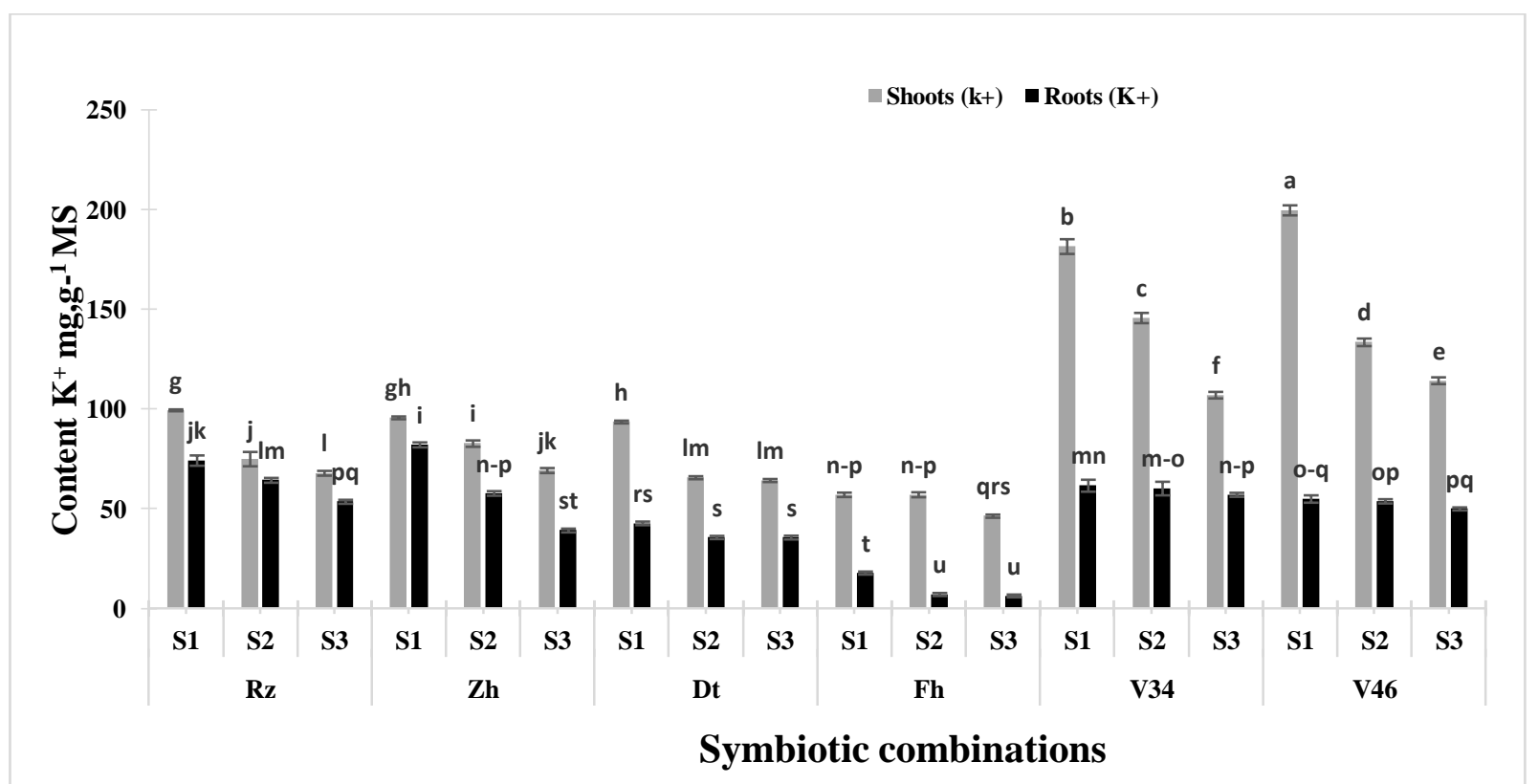

Figure 5. Effect of water deficit on the $\mathrm{K}^{+}$contents in six Moroccan chickpea genotypes (Rz, Zh, Dt, Fh, V34 and V46) inoculated with rhizobial strains. Values are means of three replicates and bars represent standard errors.

\section{$\mathrm{K}^{+} / \mathrm{Na}^{+}$ratio}

The results (Fig. 6, 7) showed that $\mathrm{K}^{+} / \mathrm{Na}^{+}$ratio was higher in the shoots than in the roots. This is in agreement with the results published by El-Iklil et al. $^{46}$. The concentration of $\mathrm{K}+$ in the cytoplasm was superior to $\mathrm{Na}^{+}$. Furthermore, in response to the drought stress, the $\mathrm{K}^{+} / \mathrm{Na}^{+}$ratio decreased in shoots and in roots in all of the studied genotypes. In shoots, Farihane variety presented the lowest value of this ratio (1.9) in association with the strain $S_{3}$, whereas V46 presented the highest value (4.5) in combination with $S_{1}$ followed by the variety V34 with a ratio of (4.3) under drought stress. A high ratio values are due to the exclusion of $\mathrm{Na}^{+}$and $\mathrm{K}^{+}$ accumulation ${ }^{47}$ and the $\mathrm{K}+/ \mathrm{Na}+$ ratio shows the threshold of toxicity by $\mathrm{Na}+$. Indeed, a high ratio shows a low toxicity and consequently a better tolerance for plants to drought stress ${ }^{48,41}$. 


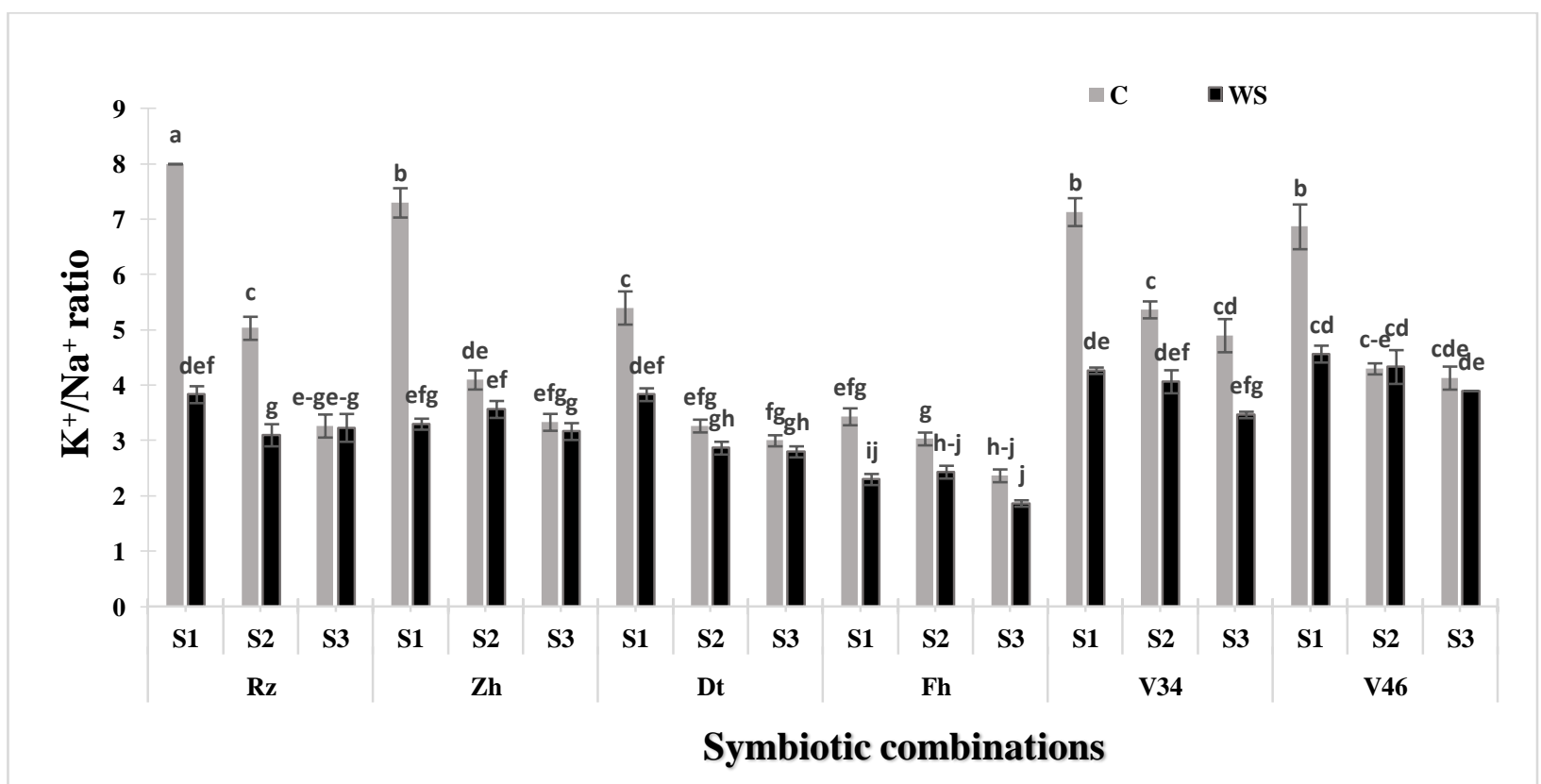

Figure 6. Effect of the water deficit on the $\mathrm{K}^{+} / \mathrm{Na}^{+}$ratio in shoots of six Moroccan chickpea genotypes (Rz, Zh, Dt, Fh, V34 and V46) inoculated with rhizobial strains. Values are means of three replicates and bars represent standard errors.

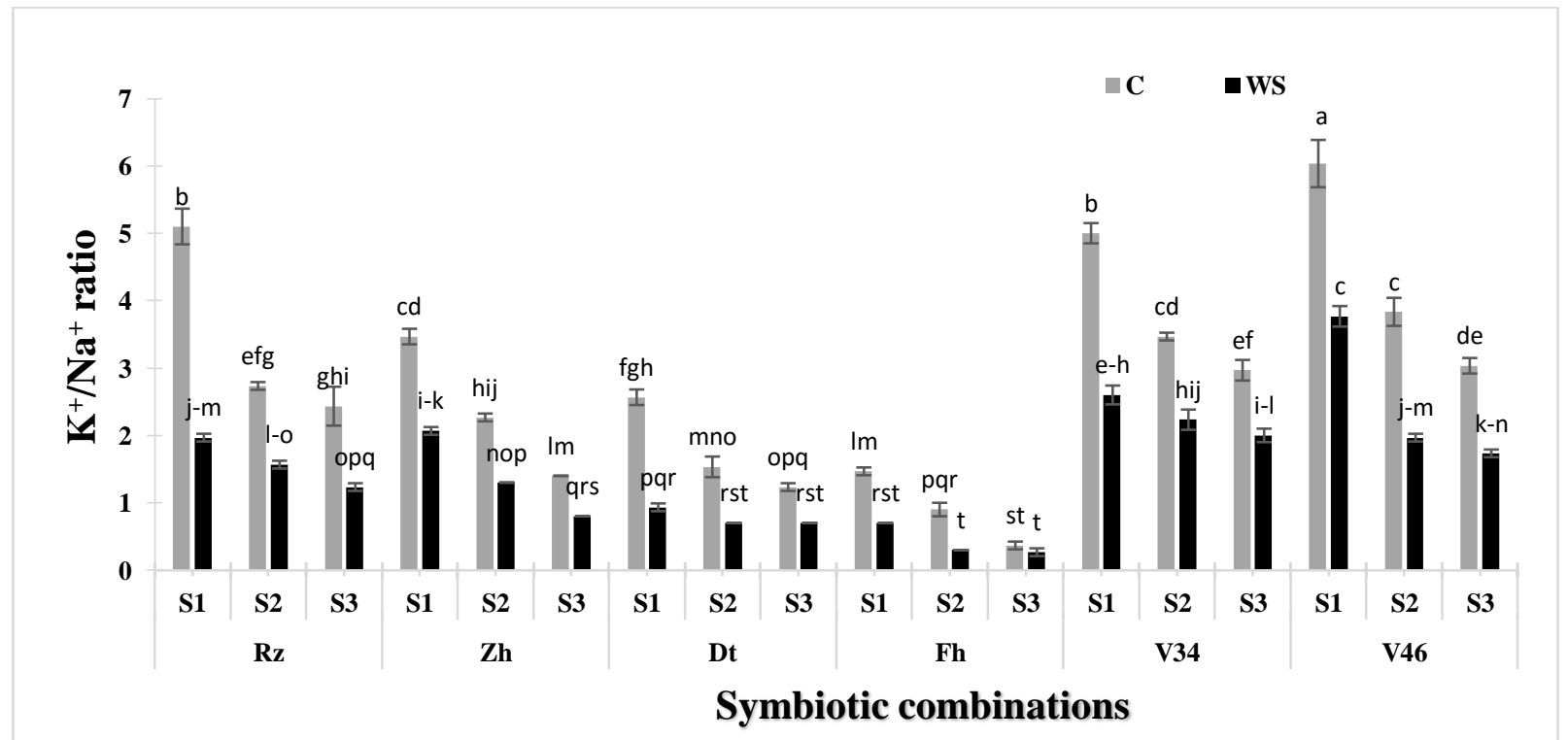

Figure 7. Effect of the water deficit on the $\mathrm{K}^{+} / \mathrm{Na}^{+}$ratio in roots of six Moroccan chickpea genotypes (Rz, Zh, Dt, Fh, V34 and V46) inoculated with rhizobial strains. Values are means of three replicates and bars represent standard errors.

\section{CONCLUSION}

In the arid and semi-arid regions as in the south of Morocco, the drought becomes a factor limiting for the crop production.To decrease its effect, the use of drought tolerant combination varieties-rhizobia is of primordial interest.The growth and nutritional uptake variables enabled us to justify this choice and also to find very strong correlations between them. According to our results the combinations V46-S

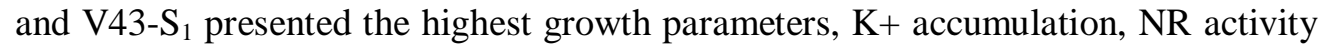
and less $\mathrm{Na}+$ content in their shoots, roots and especially in the nodules. While the 
drought-sensitive variety is formed by combination Dt- $\mathrm{S}_{3}$, present the lowest growth rate, nodulation values and $\mathrm{K}^{+} / \mathrm{Na}^{+}$ratio. The intermediate tolerant-drought combination is formed by Fh- $\mathrm{S}_{1}$.

\section{REFERENCES}

1-FAO (Food and Agriculture Organization of the United Nations). Agricultural production year book/ or http://faostat.fao.org ;2010.

2-Mwanamwenge J, Loss SP, Siddique KHM, and Cocks PS. Growth, seed yield and water use of faba bean (Vicia faba L.) in a short-season Mediterranean-type environment. Aust J Exp Agric. 1998; 38: 171-180.

3-Asghari B, Rashida B, Dazzo F. Adaptation of chickpea to desiccation stress is enhanced by symbiotic rhizobia. Symbiosis. 2010; 50: 29-133.

4-Singh KB, Malhotra RS, Halila MH, Knights EJ, Verma MM. Current status and future strategy in breeding chickpea for resistance to biotic and abiotic stresses. Euphytica. 1994; 73: $137-149$.

5-Muhammad A, Aafia I. Drought stress induced changes in some organic substances in nodules and other plant parts of two potential legumes differing in salt tolerance. Flora. $2005 ; 200$ (6):535-546.

6-Gaur YU, Sen AN. Cross inoculation group specificity in Cicer-Rhizobiumsymbiosis. New Phytol. 1979; 83: 745-754.

7-Mouradi M, Farissi M, Bouizgaren A, Makoudi B, Kabbadj A,Very AA, et al. Effects of water deficit on growth, nodulation and physiological and biochemical processes in Medicago sativa-rhizobia symbiotic association. Arid Land Res Manag. 2016; 30(2): 193208.

8-Sinclair TR, Zimet AR, Mucho RC. Changes in soybean nodule number and weight in reponse to drought. Field Crop Res. 1988; 18: 197-202

9-Samir BR, Mustapha T, Mohamed EA, Philippe L, Ridha M. The diversity of rhizobia nodulating chickpea (Cicer arietinum) under water deficiency as a source of more efficient inoculants. Soil Biol Biochem. 2009; 41: 2568-2572.

10-Zhang J, Nguyen HT, Blum A. Genetic analysis of osmotic adjustment in crop plants. J Exp Bot. 1999, 50: 291-302.

11-Iannucci A, Russo M, Fonzo ND, Martiniello P. Water deficit effects on osmotic adjustment and solute accumulation in leaves of annual clovers. Eur J Agron. 2002; 16: 111122.

12-Ullah I, Ur-Rahman M, Ashraf M, Zafar Y. Genotypic variation for drought tolerance in cotton (Gossypium hirsutum L.): Leaf gas exchange and productivity. Flora. 2008; 203: 105115.

13-Hoff T, Stummann BM, Henningsen KW. Structure, function and regulation of nitrate reductase in higher plants. Physiol Plant. 1992;84: 616-624.

14-Arrese-Igor C, González EM, Marino D. Physiological responses of legume nodules to drought. Plant Stress. 2011; 5: 24-31.

15-Osonubi O, Oren R, Werk KS, Schulze ED. Performance of two Picea abies (L) karst. Stands of different stages of decline. IV. Xylem sap concentrations of magnesium, calcium, potasium and nitrgen. Oecol. 1988; 77: 1-6.

16-Greenway H, Munns R. Mechanisms of salt tolerance in non-halophytes. J Ann Rev Plant Physiol. 1980; 31: 149-190.

17-Munns R.Comparative physiology of salt and water stress. Plant Cell Environ. 2002; 25: 239-250.

18-Byrt CS, Platten JD, Spielmeyer W, James RA, Lagudah ES, Dennis ES, et al.HKT1;5-Like Cation Transporters Linked to $\mathrm{Na}^{+}$Exclusion Loci in Wheat, Nax2 and Knal.Plant. Physiol. 2007; 143(4) 1918-1928.

19-Tester M, Davenport R. $\mathrm{Na}^{+}$tolerance and $\mathrm{Na}^{+}$transport in Higher Plants. Ann Bot.2003; 91: 503-527.

20-Wakeel A, Abd-El-Motagally F, Steffens D, Schubert S. Sodium induced calcium deficiency in sugar beet during substitution of potassium by sodium. J Plant Nutr Soil Sci. 2009; 172: 254-260. 
21-Wakeel A, Steffens D, Schubert S. Potassium substitution by sodium in sugar beet (Beta vulgaris) nutrition on K-fixing soils. J Plant Nutr Soil Sci. 2010; 173: 127-134.

22- Anselm AE, Taofeeq AA. Challenges of Agricultural Adaptation to Climate Change in Nigeria: a Synthesis from the Literature. Field Actions Sci Reports. 2010; 4: 1-11.

23- Vincent JM. A Manual for the Practical Study of Root Nodule Bacteria. Oxford: Blackwell Scientific; 1970.

24- Heuer B, Plaut Z. Reassessment of the In vivo Assay for Nitrate Reductase in Leaves. Physiol. Plant. 1978; 43: 306-312.

25-Brugnoli E, Björkman O. Growth of cotton under continuous salinity stress: Influence on allocation pattern, stomatal and non-stomatal components of photosynthesis and dissipation of excess light energy. J Planta. 1992; 187: 335-347.

26-Bernstein N, Läuchli A, Silk WK. Kinematics and dynamics of sorghum (Sorghum bicolor L.) leaf development at various $\mathrm{Na} / \mathrm{Ca}$ salinities. I. Elongation and growth. J Plant Physiol. 1993;103: 1107-1114

27-Ashraf MY, Iram A. Drought stress induced changes in some organic substances in nodules and other plant parts of two potential legumes differing in salt tolerance. Flora.2005; 200: 535-546.

28-Latrach L, Farissi M, Mouradi M, Makoudi B, Bouizgaren A, and Ghoulam C. Growth and nodulation of alfalfa-rhizobia symbiosis under salinity: Electrolyte leakage, stomatal conductance, and chlorophyll fluorescence. Turk J Agric For. 2014; 38: 320-26.

29-Pacucci GC, Troccoli B, Leoni B. Effect of supplementary irrigation on yield of chickpea genotypes in a Mediterranean climate. Agric Eng Int.2006; 8

30-Gouia $\mathrm{H}$, Ghorbal $\mathrm{MH}$, Touraine $\mathrm{B}$. Effects of $\mathrm{NaCl}$ on flows of $\mathrm{N}$ and mineral ions and on NO3-reduction rate within whole plants of salt-sensitive bean and salt-tolerant cotton. Plant Physiol.1994; 105: 1409-1418.

31-Ligero F, Lluch C, Olivares J. Evolution of ethylene from roots and nodulation rate of alfalfa (Medicago sativa L.) plants inoculated with Rhizobium meliloti as affected by the presence of nitrate. J Plant Physiol.1987; 129(5): 461-467.

32-Flowers TJ, Hajibaghieri MA, Yeo AR. Ion accumulation in the cell walls of rice plants growing under saline conditions: Evidence for the Oertli hypothesis. J Plant Cell Environ. 1991; 14: 319-325.

33-Rush DW, Epstein E. Comparative studies on sodium, potassium and chloride of a wild halophytic and adomestic Salt-sensitive tomato species. J Plant Physiol. 1981; 68: 13081313.

34-Elumalai RP, Nagpal P, Reed JW.A mutation in the Arabidopsis KT2/KUP2 potassium transporter gene affects shoot cell expansion. Plant Cell. 2002;14: 119-131.

35-Sairam RK, Tyagi A. Physiology and molecular biology of salinity stress tolerance in plants. Curr Sci. 2004; 86: 407-421.

36- Misra N, Dwivedi UN. Genotypic difference in salinity tolerance of green gram cultivars. Plant Sci. 2004; 166: 1135-1142.

37- Mengel EA, Kirkby EA. Principles of Plant Nutrition. Kuwer Academic Publishers. Dordrecht; 2001.p. 36-54.

38-Dubcovsky J, Santa Maria G, Epstein E, Luo M-C,Dvoøák J. Mapping of the $\mathrm{K}^{+} / \mathrm{Na}^{+}$ discrimination locus Kna1 in wheat. Theor Appl Genet. 1996; 92: 448-454.

39-Botella MA, Vartinez V, Pardines J, Cedra A. Salinity induced potassium deficiency in maize plants. J Plant Physiol. 1997; 90: 1408-1416

40-Garcia A, Rizzo CA, Din JVD, Bartos SI, Senadhira TJ, Flowers TJ, Yeo AR. Sodium and potassium transport to the xylem are inherited in dependently in ice, and the mechanism of sodium: potassium selectivity differs between rice and wheat. Plant Cell Environ. 1997; 20: $1167-1174$.

41-Ashraf M, Shahbaz M, Mc Neilly T. Phylogenetic relationship of salt tolerance in early green Revolution CIMMYT wheat. Environ Exp Bot. 2005;53 (2): 173-184

42-De Lacerda CF, Cambraia J, Oliva MA, Ruiz HA. Changes in growth and in solute concentrations in sorghum leaves and roots during salt stress recovery. Environ Exp Bot. 2005; 54(1): 69-76.

43-AL-Zahrani HS and A.A. AL-Toukhy. Growth and mineral constituents of prose millet (Pennisetum glaucum) irrigated with seawater. Life. Sci. J. 2012; 9(3), 67-72 
44-Bayuelo-Jiménez JS, Debouck DG, Lynch JP. Growth, gas exchange, water relations and ion compostition of Phaseous species grown under saline conditions. Field Crops Res. 2003;80: 207-222.

45-Sharma SK., Kumar S. Effect of salinity on $\mathrm{Na}+\mathrm{K}+$ and $\mathrm{Cl}$-content in different organs of chickpea and the basis of ion expression. Biol Plantarum. 1992; 34: 311-317.

46-El-Iklil Y, Karrou M, Mrabet R, Benichou M. Effet du stress salin sur la variation de certains metabolites chez Lycopersicon esculentum et Lycopersicon sheesmanii. Can J Plant Sci. 2002 :82: 177-183.

47-Dasgan HY0, Aktas H, Abak K, Cakmak I. Determination of screening techniques to salinity tolerance in tomatoes and investigation of genotype responses. Plant Sci. 2002;163 : 695-703.

48-Wei W, Bilsborrow PE, Hooley P, Fincham DA, Lombi E, Forster BP. Salinity induced diffrences in growth, ion distribution and partitioning in barley between the cultivar Maythorpe and its derived mutant Golden promise. Plant Soil. 2003; 250 (2): 183-191.

Received: May07, 2016; Accepted: June01, 2016 